\title{
A Qualitative Approach to Analyze Marketing Communication Based on AIDA Model
}

\author{
${ }^{1}$ Fazal ur Rehman*, ${ }^{1}$ Farwida Javed, ${ }^{1}$ Shabir Hyder, ${ }^{2}$ Sadaqat Ali \\ ${ }^{1}$ COMSATS Institute of Information Technology, Attock Campus, Pakistan \\ 2University of Science \& Technology Bannu, Pakistan \\ *Fazal_marwatpk@yahoo.com
}

\begin{abstract}
In present spirited business environment, marketers and advertisers are facing trouble in the selection of viable marketing channels. Obviously, mobile phone and electronic mail are the two interesting communication sources. This study aims to emphasize on the effectiveness of mobile and email marketing channels using AIDA model. The study applied qualitative approach to collect data through semi-structured interviews from the registered customers of a retailer and whole sales company "Metro-Habib Cash \& Carry Pakistan (MHCCP)". The collected data were analyzed through matrix structure by defining themes and color codes. The sub-rows and columns were re-arranged with the help of iterative approach to properly manage the data. The study clarified that mobile marketing channel creates better market attention, interest, desire and purchase action as compared to email marketing channel.
\end{abstract}

Keywords: Mobile Marketing, Email Marketing, Qualitative Approach, Matrix Structure, AIDA Model

\section{Introduction}

The mode of marketing communication has altered due to advancement in information and communication technology and the distances among businesses and their customer's has minimized. Now it has become easy for a business to interact its customer's at lower cost and in shorter period of time around the globe. Mobile and email are the examples of advanced communication in today business environment. Mobile marketing is the use of mobile as a mean of marketing communication. This idea has defined by Shankar and Balasubramanian's (2009) that mobile marketing is "the two-way or multi-way communication and promotion of an offer between a firm and its customers using a mobile medium, device". Researchers highlighted another aspect of mobile marketing that it is an efficient source to get positive response from customer's (Barwise \& Strong, 2002). Mobile marketing is primarily interactive in nature and includes mobile advertising, promotion, customer support, and other relationship building activities. Therefore, mobile phone is facilitating new channel for reaching and interacting with consumers (Trappey \& Woodside, 2005).

Businesses are adopting mobile marketing as a regular communication channel for customer services, promotional updates and tracking customer's orders. Various international business organizations like Estee Lauder a personal care product company is using SMS coupons for the promotion of its products, McDonald's is offering quizzes and competitions via SMS to raise its sales and brand awareness and Nike a leading multinational company of sports goods is using mobile marketing to facilitate consumers in their choices (Shankar \& Balasubramanian, 2009). Similarly, electronic mail (E-mail) is also widely used marketing channels around the world. It defined as "Email marketing is the business practice of sending an email to people on a list in the hopes of selling them a product or service (Gardner, 2012)". It is an important medium of marketing communication especially for companies seeking to build and maintain closer relationships with customers (Fiona \& Neil, 2011).

However, advertisers are using mobile and email as a marketing communication tool to draw attention of customers to their ads by means of a variety of advertising techniques. The theory of hierarchy of effects is often used by researchers in testing the effects of advertisement. Hierarchy of effects model was initially introduced to assess the immediate and media- specific effects of campaigns (Cavill \& Bauman, 2004). It is a linear theory of marketing and advertising which presumes that the consumers must go through a rational and sequential series of steps that ends up in e.g. attention, interest, desire and purchase decision (Grover \& Vriens, 2006). Hierarchy of effect is the theoretical background and AIDA is the efficient and appropriate model of the study. Therefore, the aim of the study is to assess mobile phone and email as communication 
channels for conveying the message of a business to its customers. The study will assess the significance of mobile and email as effective marketing tools and will compare these two marketing channels to identify preferable one. This study is unique in the sense that comparison between both the channels based on AIDA model and will analyze data through matrix structure.

\section{Literature Review}

Hierarchy of effects Theory: Advertisers are applying a variety of techniques to draw attention to their ads and apply hierarchy of effect theory to assess the influence of advertisements. Initially hierarchy of effect model was developed in 1898 by St. Elmo Lewis (attention, interest and desire) known as AID and then (Strong \& Edward, 1922) described that how sales people had to attract attention, maintain interest and create desire (AID) in order to be successful and creating long term relationship. Shortly thereafter, Lewis added a fourth step "get action" to his original model. This model came's to be known as AIDA and is still one of the referred models in the advertising and personal selling literature, concerning how people behave in responding to sales and advertising presentations of a business (Barry, 1987).

Lavidge and Steiner (1961) introduced the idea that consumers do not go automatically to the purchase decision without taking interest in other steps of advertisement. They go through a series of seven steps to that threshold of purchase: Unawareness, Awareness, Knowledge, Liking, Preference, Conviction, and Purchase but the unawareness is not a necessary step of the series. Lavidge and Steiner (1961) also felt that it is also possible that some consumers develop a negative attitude towards these steps. Therefore, some of the steps has to be removed and the model was modified to three steps; Cognition (awareness or learning), Affect (feeling, interest or desire) and Behavior or conation (action). Lavidge and Steiner (1961), model is also known as the hierarchy of effects model. According to Smith, Chen and Yang (2008), with the passage of time, marketers and researchers described the different stages, different steps and sequences of hierarchy of effects model but always has been a generalized form as a sequence of Cognition (attention), Affect (interest or desire) and in the end Conation (purchase).

Mobile Marketing: Today the environment of doing business has totally changed due to complexity and antagonism created by globalization and improvement in communication technology (Kotler, 1999). "Advances in information and communication technologies are not only offering new marketing channels for companies but also significantly influencing the ways in which companies conduct their businesses and marketing activities" (Barutcu, 2008). Due to the reason, businesses are turning towards digital technology to improve their marketing channels and to reach efficiently to their target audience. For instance, businesses have adopted mobile phone as a marketing channel to cope with the major challenges e.g. time and attention from customers. Mobile phone users have positive perceptions towards mobile marketing as it saves consumer's time, money and providing useful information (Standing et al., 2005). Mobile marketing is a source to reach unlimited customers in seconds (Haig, 2002; Richardson, 2010). This idea is further supported by (Barwise \& Strong, 2002), that mobile marketing is the efficient source get positive response from target audience. Consumers show a positive attitude towards advertising message through mobile marketing (Haghirian et al., 2005). Further, mobile marketing is the fastest source for delivering marketing messages to target audience (Scharl et al., 2005). Therefore, marketers and advertisers are spending a huge amount of money in their marketing activities on mobile channel around the globe. Marketers are investing to use mobile phone as an advertising channel with new features as compared to traditional media (Karjaluoto et al., 2004). World leading brands like Pepsi, Coca Cola, Adidas, Mazda, MacDonald's, Nike, Disney, MTV, Volvo, and many other are using mobile advertisement from last several years (Sultan \& Roham, 2005; Bauer et al., 2005). Businesses are adopting mobile marketing as a regular communication channel for customer services, promotional updates and tracking customer's orders.

Email Marketing: Email marketing is a type of direct communication where a business sends its commercial message to an individual or a group of people who are using email. Electronic mail (E-mail) is one of the widely used marketing channels around the world. In a broad sense, all types of email like ads, business request, and brand awareness would be considered as email marketing (US Interactive Marketing Forecast, 2013). It is defined by a study as "Email marketing is the use of email as a direct marketing channel" (Brassington \& Pettitt, 2003). According to another definition "Email marketing is the business practice of 
sending an email to people on a list in the hope of selling them a product or service" (Gardner, 2012). Email marketing enable businesses to reach million people and receiving their replies around the globe in seconds (Kinnard, 2002). It enables businesses to convey on time information that enhances personalization (Nussey, 2004). It enables marketers to track the actions of targeted customers through analyzing results on actual time (Blumberg et al., 2005). Transactional email and direct email are the important types of email marketing.

Analysis Model of Marketing Communication: In common senses, marketing communication is the coordinated promotions of a business where it delivers messages to their audience through one or several communication channels. Marketing communication is the promotional part of the marketing mix and is the process of sending, encoding, transmission medium, decoding and receiver. Therefore, a classical model of marketing communication is described by Duncan and Mariarty (1998) and is illustrated as follows:

Figure 1: Illustration of Communication based Marketing Model - Duncan \& Mariarty (1998)

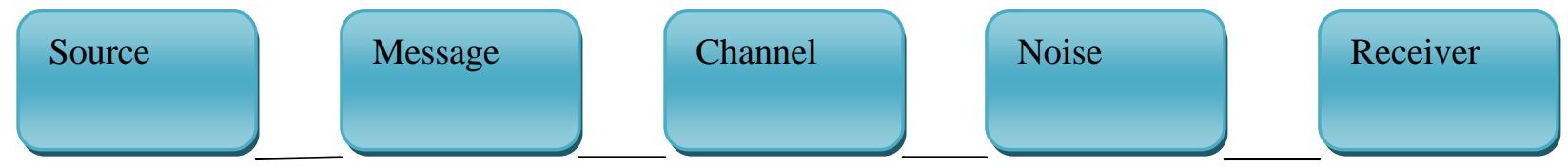

The problem of the study is to examine the mobile and email communication channels that how these channels can affect the responses of consumers. In this illustration noise is not considered as it is not measured by analyzing process. Here, through this analysis model the study have to investigate and determine the effective marketing channel when sending a marketing message through different communication channels i.e. mobile and email marketing channel.

Figure 2: Illustration of analysis model

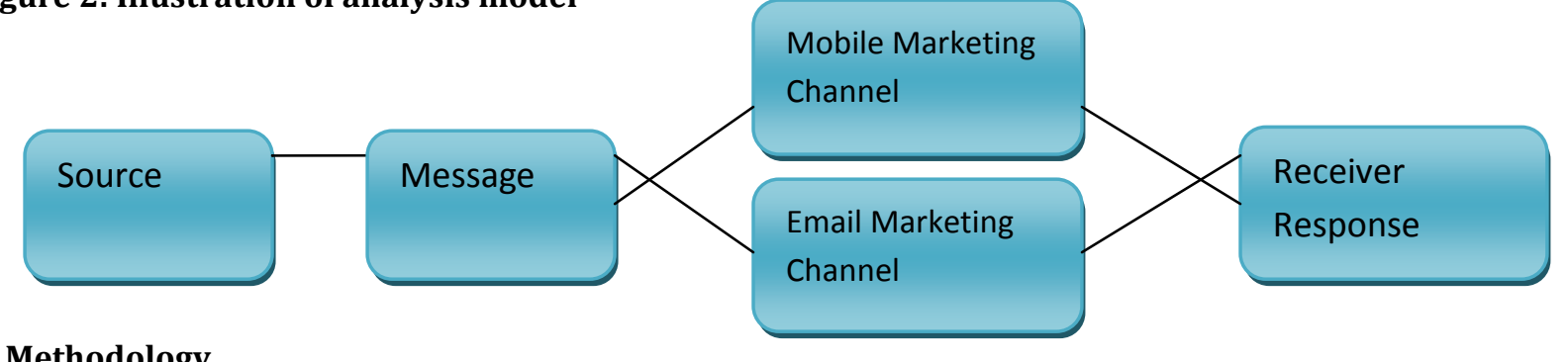

\section{Methodology}

Qualitative approach is the choice of the study and semi structured interview is the data collection tool along with deductive approach. Qualitative approach is inductive while generating a new theory but is considered deductive when a study tries an existing theory (Bryman \& Bell, 2005; Hyde, 2000). The study collected primary data from the registered customers of MHCCP 'which is a famous retailer and whole sales consumer products company in Islamabad' through convenient approach. Hierarchy of effect is the theoretical background and AIDA is the appropriate model of the study. All the registered customers of MHCCP in Islamabad and Rawalpindi are the population and a small portion of the whole population is the sample of the study. The study used a stratified probability sampling approach where the sample is divided into homogenous non overlapping groups. Two stratums (Mobile \& Email) are chosen for the study with a random sample of 24 registered customers (12 for each stratum).

Connection with theory \& Literature: The study operationalized the theory and derived some questionnaires from it to collect data through semi-structured interviews. These questionnaires are connected to the theoretical background of the study.

Method of Data Analysis: The study applied Matrix structure to analyze the collected data. Generating categories or designing an appropriate matrix structure for the placement of collected data into its cells is used for data analysis (Dey, 1993; Miles \& Huberman, 1994; Yin, 1994). The study applied the recommended matrix structure and pattern of Philipson (2011) for data analyses. 
Figure 3: Analysis Method - Philipson (2011)

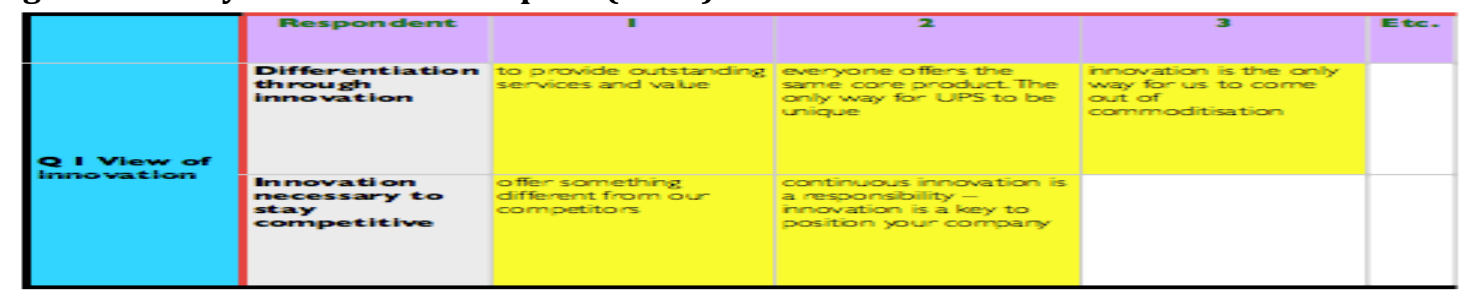

Themes of interviews: The study thoroughly and carefully checked the interviews chart to improve the validity and identified some keywords or themes from interviews data for making comparison. The key words are developed on the basis of similarities and differences in the respondent's answers. Themes are produced on the basis of similarities and differences in the respondent's views (Ryan \& Bernard, 2003).

Developing color codes for answers: Analyzing qualitative data is slight difficult than quantitative, therefore, it is mandatory to code the interviews answers for both the channels by color in the designed matrix structure. The study applied sky blue color for mobile marketing channel and red color for email marketing channel. Relevant cells are coded in matrix structure.

Re-arrangement of matrix sub-rows and column: The study used a systematic approach for the rearrangement of matrix sub-rows and columns. This re-arrangement for sub-rows is done by heading some generic keywords. Sub-rows with the highest number of colored cells were placed first then sub-rows with the second highest number of colored cells on the second position and so on. Similarly, for the rearrangement of columns, the study arranged the respondents who provided similar information and next to each other with the help of iterative approach.

\section{Results Analysis}

Analyzing results for Mobile Marketing

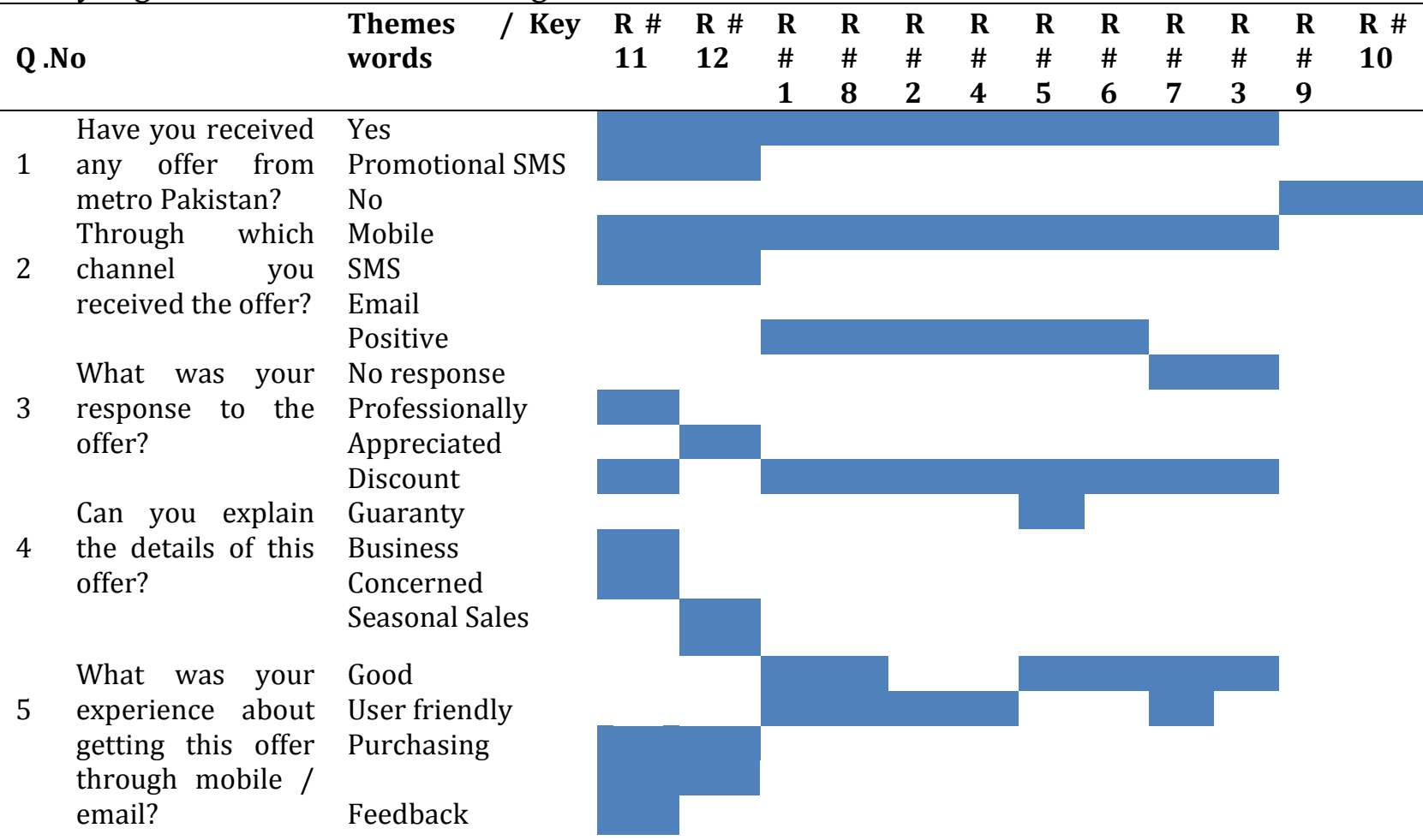




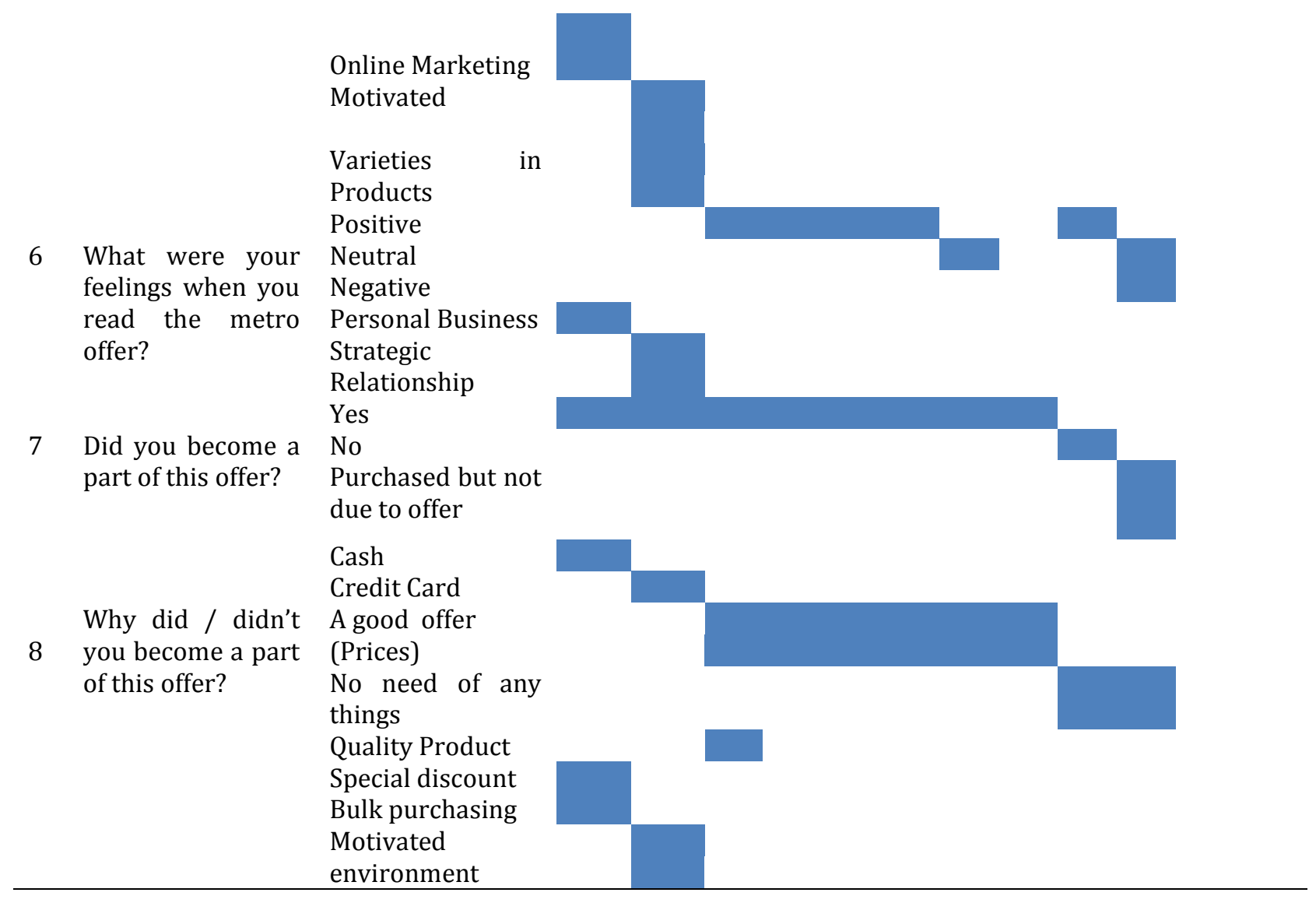

The above matrix structure shows the complete depiction of mobile interviews of MHCCP registered customers. In the developed structure the colored cells indicate the customer's perceptions and answers about the asked questions. The study asked the first question from 12 registered customers of MHCCP to note their views about mobile marketing in the sense to create attention. In these 12 registered customers only 8 respondents answered that they have received the offers on their mobile from the company but did not clear the style of the offer (i.e. SMS or Call). Two respondents cleared that they have received a promotional SMS on their mobile. Two respondents told that they never received any offer from the company on their mobiles. So the answers of all the respondents are placed in concerned cells (8 in yes cells, 2 in promotional SMS and 2 in no cells). The second question was about the source of channels where 8 respondents answered that they have received this offer on their mobile (i.e. Mobile channel). Two respondents answered that they have received the offer on their mobile and further cleared that it was in SMS form. The two remaining respondents did not provide any further information. Therefore, all the respondents' answers are placed in the concerned cells of the structure.

The study asked third question from the respondents to know about their feelings toward the company offers. Six respondents answered that they feel the offer positively and showed interest in the offers. Two respondents replied that they ignored the offers and did not provide further information's. One participant answered that he responded professionally and one respondent appreciated their offer. The answers of six respondents are placed in the cells that are headed by "positive" key word, another two in the cells which are headed by "No response" and remaining two in their concerned cells. The next question is about the details of the offers where seven respondents cleared that it was about the discount of the product prices. One participant answered that he observed it about the discount of the products and its guarantee as well. One respondent noted that it was concerned with his business and one respondent told that the promotional offer of MHCCP was about seasonal sales, while, two respondents did not provide any data. Fifth question is about the deep involvement of the offers (means desire). The study asked the question to know the respondents' views about the offer involvement. Three respondents answered that it was good and friendly user which 
show the deep involvement in the offer. Three respondents answered that MHCCP offer was good and two answered that it was user friendly. One respondent answered that mobile marketing made it possible to give feedback about previous purchasing and got experience about online marketing. One respondent said that mobile marketing motivated him towards purchasing, where as some respondents did not reply. The next question was about the inner feelings of the respondents. Here it was try to know the respondents' feelings about the offers. To this particular question five respondents answered that they feel positive, two respondents remained neutral and only one respondent show negative attitude. One respondent answered that their offer was concerned with his personal business and one told that MHCCP is trying to develop strategic relationship with a market through mobile marketing.

Seventh question is about the actual action of purchasing where it was seek to know about the real sales of the company due to mobile advertising. Six respondents answered that they purchased the products due to offer, one respondent told that he did not become a part of the offer. One respondent answered that he is purchasing from the company but not due to any offer. One respondent answered that he purchased there directly in cash and one told that he purchased through credit card. In the final question, five respondents purchased due to a very good offer, two respondents did not purchase because of no needs and one respondent purchased because of quality products and a good offer. One respondent answered that he purchased there because of special discount on bulk purchasing and one told that he purchased from MHCCP because of highly motivated business environment.

Analyzing results for email marketing:

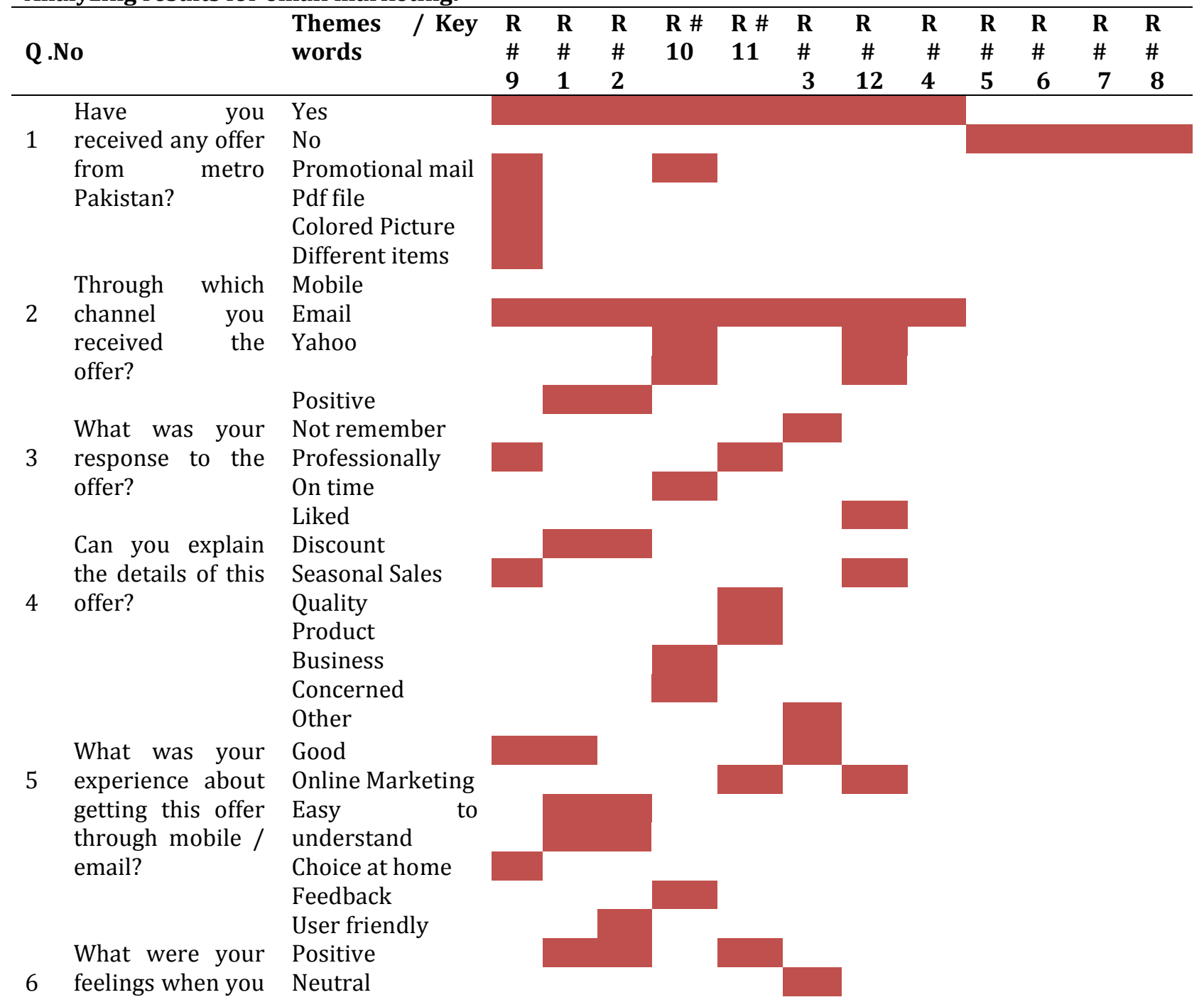




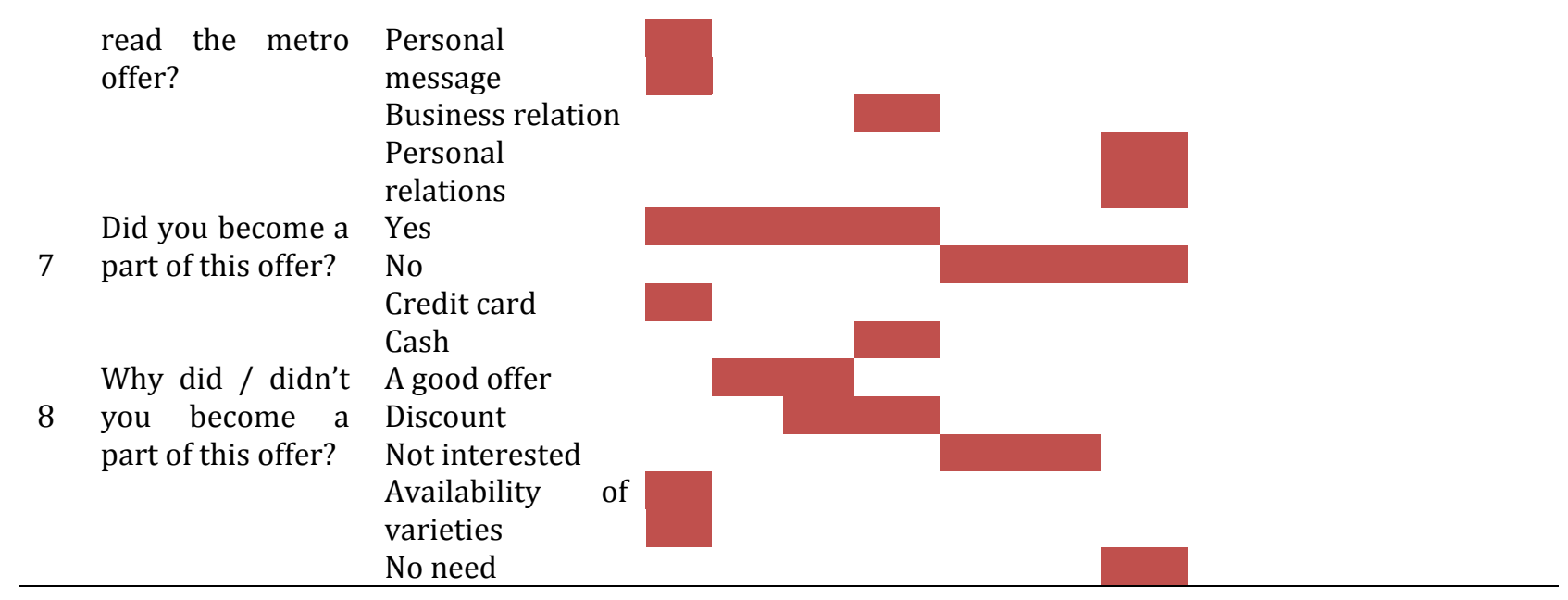

The study enquired first question from 12 customers of MHCCP to know their views about email marketing. From the 12 customers of the MHCCP, 8 respondents answered that they have received promotional messages from the company in their email Inbox. Respondent 10 further cleared that it was a promotional mail and respondent 09 told that he received a promotional mail in Pdf file with colored picture of different products. Four respondents told that they never received any promotional email from the company. So the answers of all the respondents are placed in concerned cells (8 in yes cells, 4 in No cells and other information in the related cells). The second question of the interview was about the source of channels where 8 respondents answered that they have received the promotional emails from the company (i.e. Email channel). Two respondents further cleared that they received this email on their yahoo mail ID. The other remaining respondents did not provide any further information. Therefore, all the information's are placed in the concerned cells. The study interviewed the next question from the respondents to know about their feelings toward the company offers. Two respondents replied that they feel the offer positively and showed interest in it. Other two participants answered that they responded professionally, one respondent cleared that he responded to their mail on actual time. One respondent liked their promotional mail and one of them replied that he has forgotten about the offer. The remaining five respondents did not provide any further information's.

The fourth question is about the details of the offers where two respondents answered that it was about the discount of the product prices, two respondents answered that the MHCCP email was about seasonal sales and one respondent told that their mails are concerned with quality products. One respondent answered that their emails are relevant with their business. One respondent answered that he has no idea about the offer and the remaining five respondents did not provide any further information's. Next question is about the deep involvement of the offers (means desire). The study interviewed the question to know the respondents' views about the offer involvement. Respondent 09 answered that the promotional email of MHCCP was good because he was able to make choices at home. Respondent 01 answered that their mail was good and easy to understand. Respondent 10 answered that he was able to send them a feedback email. One respondent answered that their promotional offer is like online marketing. Respondent 03 told that their mail was very good and one respondent answered that MHCCP is adopting online marketing to serve their customers which show the deep involvement in the offer. Other remaining respondents did not show their views about this question. In question sixth, the study asked about the inner feelings of the respondents. Here interviewer tried to know the respondents' feelings about the offers. To this particular question three respondents answered that they feel positive, one respondent remained neutral and one respondent answered that MHCCP have sent him a personal message. One respondent said that MHCCP is trying to adopt business relations while the other answered that they are creating personal relations with their customers.

Seventh question is about the actual purchasing where the study tried to know about the real sales of the company due to email advertisement. Four respondents answered that they purchased the products due to offer. One participant further told that he purchased there on cash and one through credit card. Three respondents told that they did not become a part of the offer and other remaining respondents did not 
become the part of the question. The final question is about the reasons of purchasing where researcher tried to know the real causes of purchasing. Two respondents answered that they purchased due to a very good offer which they received from the company. Two respondents answered that it was a good and discounted offers and two respondents said that they were not interested in the offer. One respondent told that he purchased there because of the different varieties of items available with them. One respondent answered that he did not purchase there because he had no need.

\section{Analyzing results with Theory}

Response percentage of AIDA Model: For the clarification of respondent's views it was considered necessary to know about their percentage ratios that are as follow:

Table 1: Percentage illustration of responses with respect to AIDA model

\begin{tabular}{lllll}
\hline $\begin{array}{l}\text { Marketing } \\
\text { Channel }\end{array}$ & Attention & Interest & Desire & Action \\
\hline Mobile response & $83.3 \%$ & $67 \%$ & $83.3 \%$ & $67 \%$ \\
Email response & $67 \%$ & $50 \%$ & $58.3 \%$ & $33.3 \%$ \\
\hline
\end{tabular}

Attention: The interviews data reflects that 83.3 percent of the mobile respondents have received an offer from MHCCP. These respondents confirmed that they have received a promotional SMS and calls from MHCCP but 20 percent respondent did not receive any offer from the company. Likewise, 67 percent email respondents confirmed that they have received a promotional email from the MHCCP and 33 percent respondents told that they did not receive any offer. 83.3 percent of mobile and 67 percent of email respondents confirmed that they have received an offer from MHCCP and confirmed about the first step of hierarchy of effects, i.e. Attention. One participant also confirmed during his interview that MHCCP has main focus on mobile marketing channel rather than email marketing channel.

"Company is focusing on the mobile marketing channel to create market attention rather than email because customers giving preferences to mobile marketing channel".

On the basis of results and other arguments it is assumed that mobile creates greater market attention than email.

Interest: The Interview data indicates that 67 percent of the mobile respondents had shown positive feeling about the promotional offer, 17 percent did not respond and 16 percent did not receive any offer from the company. Here the mobile respondents involved in the promotional offer and moved from the attention stage to the interest stage of hierarchy of effects model. Similarly, from the email sample, the data shows that only 50 percent of the respondents had shown interest in the promotional offer, 8.3 percent said that they have no idea, 8.3 percent did not provide any information and 33 percent respondents did not receive any promotional email. It is noted that MHCCP is providing updated information's about its seasonal sales, special discount, guaranteed products, varieties and many more. Sometimes, customers are perceiving that they are being treated as personally and shows greater interest in their offers. Through mobile device MHCCP is trying to build personal and business relations with targeted customers. At the same time, MHCCP is sending promotional mails to provide updated information's about seasonal sales, quality products and so on, along with colored pictures. Email marketing is providing the opportunity to make choice at home for creating greater business interest.

According to a respondent views:

"Mobile is the more interesting marketing channel than email because mobile is an advanced communication channel and its usage is higher than email".

On the basis of study results and respondents suggestions, it is assumed that mobile marketing channel is creating greater business interest than email. In this stage respondents moved from the attention to the interest step of the hierarchy of effects model.

Desire: The interviews data indicates that 67 percent mobile respondents have showed interest in the promotional offers and 83.3 percent showed desire about it. Similarly, 58.3 percent of the email respondents showed desire about the promotional offer but 8.3 percent developed some neutral feeling about it. Here in this stage the respondents automatically moved from interest to desire step of the hierarchy of effects model. 
It is noted that varieties of product and accurate mobile information's are motivating customers to show a deep involvement in business offer. Similarly, email offers are easy to understand because of colored pictures along with a price structure. However, the study results indicate that the mobile channel is creating a greater desire than email marketing channel.

Action: The interview data indicates that 67 percent of the mobile respondents took action on the promotional offer and purchased from MHCCP. These respondents enjoyed the complete process of promotional offer and passed through a sequential series of steps. These customers passed through all the steps of a hierarchy of effects model i.e. attention, interest, desire and action. Similarly, 33 percent of the email respondents became a part of the offer. They purchased the products of MHCCP. These customers involved in the complete process of promotional offer and passed through all the steps of the hierarchy of effects model. However, the study results lead to the conclusion that mobile marketing channel creates greater purchase action then email marketing channel.

\section{Figure 4: Graphical illustration of customers purchasing process in percentage}

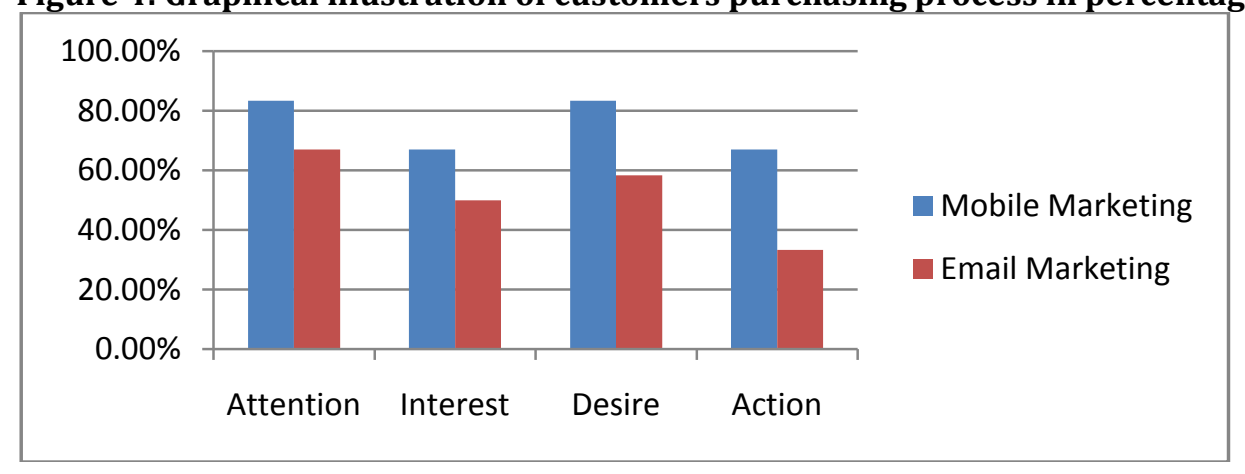

The above graphical picture illustrates that mobile marketing channel is preferable marketing channel than email marketing channel. The graph shows that mobile marketing channel creates greater attention, interest, desire, and purchase action than an email. The study further suggested that the hierarchy of effects model is the precise concept to be applied in mobile and email marketing channels. It is also assumed that mobile marketing has greater association with hierarchy of effects model as compared to Email.

\section{Conclusion}

The study assessed comparatively the effectiveness of mobile and email marketing channels to identify preferable marketing channel. The study applied qualitative approach to collect data through semi-structured interviews from the registered customers of MHCCP for both the channels. Further, the study used matrix structure for data analysis. The information's provided by respondents lead to the conclusion that mobile and email are the two important marketing channels to create market attention, interest, desire and purchase action. It is also cleared that mobile marketing channel is preferable then email marketing channel and hierarchy of effects is the precise concept to be apply for the analysis of communication channels. The study has important marketing implications by adding existing knowledge that AIDA model can be applied in qualitative study to analyze marketing communications. The managerial approach of the study was to assess the effectiveness of mobile and email marketing channels in qualitative way and assumed that mobile and email marketing channels can be analyzed through qualitative approach. This study is unique in the sense to apply qualitative approach for the analysis of communication channels with the application of AIDA model. However, while interpreting results, it is necessary to keep in views that the data collected from only one mega store and from limited number of respondents. Therefore, readers of the study should be cautious in generalizing results. To further enhance the analysis, we therefore recommend to future researchers to include other marketing channel like TV, Print media etc. Additionally, the study was only limited to consumer industry and future studies can include other sectors like services, manufacturing etc. 


\section{References}

Barry, T. F. (1987). The development of the hierarchy of effects: An historical perspective. Current Issues and Research in Advertising, 10(1-2), 251-295.

Barwise, P. \& Strong C. (2002). Permission-based mobile advertising. Journal of interactive Marketing, 16(1), 14-24.

Barutcu, S. (2008). Consumers' attitudes towards mobile marketing and mobile commerce. In Business, 8(1), $15-32$.

Bauer, H. H., Barnes, S. J., Reichardt, T. \& Neumann, M. M. (2005). Driving consumer acceptance of mobile marketing: A theoretical framework and empirical study. Journal of Electronic Commerce Research, 6(3), 181-192.

Blumberg, M., Forman, T. \& Miller, S. (2005). Sign Me Up! Lincoln, NE. iUniverse.

Bryman, A. \& Bell, E. (2005). Business Research Methods. Oxford University Press. Oxford

Brassington, F. \& Pettitt, S. (2003). Principles of Marketing $3^{\text {rd }}$.edition. Pearson Education Limited. Essex.

Cavill, N. \& Bauman, A. (2004). Changing the way people think about health enhancing physical activity: do mass media campaigns have a role? J Sports Sci., 22, 771-90.

Dey, I. (1993). Qualitative Data Analysis. London, Routledge.

Duncan, T. \& Mariarty, E. (1998). A Communication-Based Marketing Model for Managing Relationships. Journal of marketing, 62(2), 1- 13.

Fiona, E. C. \& Neil, F. D. (2011). Web advertising: The role of e-mail marketing. Journal of Business Research, 65(6), 843-848.

Gardner, B. (2012). What is Email Marketing and Why You Should be Doing It. Retrieved from: http://www.briangardner.com/email-marketing/ accessed on 15-1-2013.

Grover, R. \& Vriens, M. (2006). The Handbook of Marketing Research. Sage Publication Ltd. Thousand Oaks.

Haghirian, P., Madlberger, M. \& Tanuskova, A. (2005). Increasing Advertising Value of Mobile Marketing - An Empirical Study of Antecedents. Proceedings of the $38^{\text {th }}$ Hawaii International Conference on System Sciences. $\quad$ http://csdl.computer.org/comp/proceedings/hicss/2005/2268/01/22680032c.pdf. accessed on $22 / 11 / 2012$.

Haig, M. (2002). Mobile marketing: the message revolution, Kogan Page, London.

Karjaluoto, H., Leppdniemi, M. \& Salo, J. (2004). The role of mobile marketing in companies' promotion mix: Empirical evidence from Finland. Journal of International Business and Economics, 2(1), 111-116.

Kinnard, S. (2002). Marketing With E-mail. Canada: Maximum Press.

Kotler, P. (1999). Principles of marketing. European ed. London: Prentice Hall Europe.

Kenneth, F. H. (2000). Recognizing deductive processes in qualitative research. Qualitative Market Research: An International Journal, 3(2), 82 - 90.

Lavidge, R. C. \& Steiner, K. (1961). A Model for Predictive Measurements of Advertising Effectiveness. Journal of Marketing, 25, 59-62.

Miles, M. B. \& Huberman, A. M. (1994). Qualitative data analysis ( $\left.2^{\text {nd }} e d n\right)$, Thousand Oaks, CA, Sage.

Nussey, B. (2004). The Quiet Revolution in Email Marketing. Lincoln, NE: iUniverse, Inc.

Philipson, S. (2011). Pattern - Finding in qualitative data - A suggested method of making data analyzable. Working Paper. Accepted for Presentation at the ICAM Conference, Nassau, July18-21, 2012.

Richardson, N. (2010). Quick start guide to mobile marketing create a dynamic campaign and improve your competitive advantage. Kogen Page Ltd, London.

Ryan, G. W. \& Bernard, H. R. (2003). Techniques to identify themes. Field methods, 15(1), 85-109.

Scharl, A., Dickinger, A. \& Murphy, J. (2005). Diffusion and success factors of mobile marketing. Electronic Commerce Research and Applications, 4(2), 159-173.

Shankar, V. \& Balasubramanian, S. (2009). Mobile marketing: a synthesis and prognosis. Journal of Interactive Marketing, 23(2), 118-129.

Smith, R. E., Chen, J. \& Yang, X. (2008). The impact of advertising creativity on the hierarchy of effects. Journal of Advertising, 37(4), 47-62.

Standing, C., Benson, S. \& Karjaluoto, H. (2005). Consumer Perspectives On Mobile Advertising And Marketing. ANZMAC Conference: Electronic Marketing, 135 - 141.

Strong, L. \& Edward, K. (1922). The Psychology of Selling Life Insurance. New York: Harper \& Brothers Publishers, 
Sultan, F. \& Rohm, A. (2005). The Coming Era of "Brand in the Hand" Marketing. MIT Sloan Management Review, 47(1), 82-91.

Trappey, R. J. \& Woodside, A. G. (2005). Consumer responses to interactive advertising campaigns coupling short-message-service direct marketing and TV commercials. Journal of Advertising Research, 45(4), 382-401.

US Interactive Marketing Forecast. (2013). Email marketing. Retrieved from: http://en.wikipedia.org/wiki/Email_marketing accessed on 22 / 11/ 2012.

Yin, R. K. (1994). Case Study Research: Design and Method (2nd), Thousand Oaks, CA, Sage. 